\title{
UNITS OF MEASURE
}

No attempt has been made in this book to convert all units to the metric system. Results are recorded in the units used in the actual experiments. In general,

\section{LENGTH}

1 meter $(\mathrm{m})=39.370$ inches (based on the length of a metal bar at a specific temperature in Paris)

1 nanometer $(\mathrm{nm})=.000000001 \mathrm{~m}$

1 micrometer $(\mu \mathrm{m})=.000001 \mathrm{~m}$

1 millimeter $(\mathrm{mm})=.001 \mathrm{~m}$

1 centimeter $(\mathrm{cm})=.01 \mathrm{~m}=.39$ inch

1 decimeter $(\mathrm{dm})=.1 \mathrm{~m}$

1 kilometer $(\mathrm{km})=1,000 \mathrm{~m}=.621$ miles

1 inch $=2.54 \mathrm{~cm}$

$1 \mathrm{foot}=30.48 \mathrm{~cm}$

1 mile $=1.61 \mathrm{~km}$

\section{AREA}

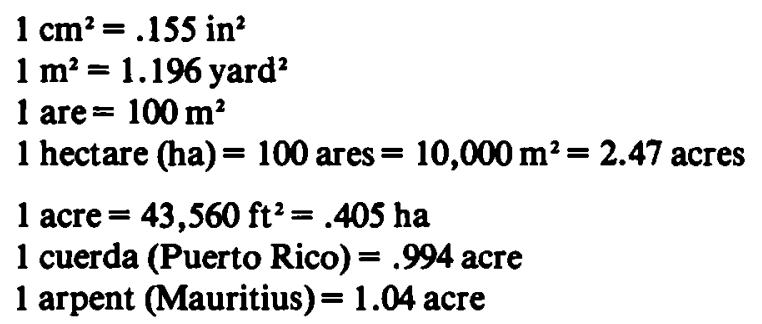

English units were used in field experiments and metric units in laboratory experiments.

\section{VOLUME}

1 cubic centimeter $(\mathrm{cc})=1$ milliliter $(\mathrm{ml})=.061 \mathrm{in}^{3}$

1 liter $(\mathrm{l})=1,000 \mathrm{cc}=.908 \mathrm{dry}$ U.S. quart $=1.057 \mathrm{li}$ quid U.S. quart

1 U.S. liquid quart $=.946$ liter

1 U.S. gallon $=231 \mathrm{in}^{3}=3.785$ liters

\section{WEIGHT}

1 gram (g) = weight of $1 \mathrm{ml} \mathrm{H}_{2} \mathrm{O}$ at maximum density in a vacuum

1 nanogram (ng) $=.000000001 \mathrm{~g}$

1 microgram $(\mu \mathrm{g})=.000001 \mathrm{~g}$

1 milligram $(\mathrm{mg})=.001 \mathrm{~g}$

1 decigram $(\mathrm{dg})=.1 \mathrm{~g}$

1 kilogram $(\mathrm{kg})=1,000 \mathrm{~g}=2.2046 \mathrm{lb}$

1 metric ton $=1,000 \mathrm{~kg}=2,204.6 \mathrm{lb}$

1 English ton (short) $=2,000 \mathrm{lb}=907.2 \mathrm{~kg}$

1 English ton (long) $=2,240 \mathrm{lb}=1,016.06 \mathrm{~kg}$

1 ounce $(\mathrm{oz})=28.35 \mathrm{~g}$

1 pound $(\mathrm{lb})=16 \mathrm{oz}=453.59 \mathrm{~g}$

\section{STATISTICAL SIGNS AND TERMS}

** = statistical significance beyond the $1 \%$ level

* = statistical significance between the $5 \%$ and $1 \%$ levels

n.s. = not significant

$t$ distribution ("student's $t$ ") is a measure of reliability of sample data (a measure of statistical significance)

$F$ ratio is obtained by dividing the mean square for treatment by the mean square for error.
LSD = least significant difference

HSD $=$ honestly significant difference

For a working understanding of these symbols as well as simple correlation, linear regression, curvilinear regression, multiple regression, variance analysis, standard partial regression, etc., the reader is referred to Snedecor and Cochran, Statistical Methods (1967), or any other standard text on statistics. 